Review Article

\title{
Vaccine against Jembrana Disease Virus Infection: A Summary Findings
}

\author{
${ }^{1,2}$ Asmarani Kusumawati, ${ }^{3}$ Tenri Ashari Wanahari, ${ }^{4}$ Pudji Astuti, \\ ${ }^{5}$ Kurniasih, ${ }^{3}$ Basofi Ashari Mappakaya and ${ }^{6}$ Hastari Wuryastuty \\ ${ }^{I}$ Departement of Reproduction, Faculty of Veterinary Medicine, \\ Gadjah Mada University, Jalan fauna no.2, Yogyakarta, 55281 Indonesia \\ ${ }^{2}$ Centre of Biotechnology Study, Gadjah Mada University, Jalan teknika utara, Yogyakarta, 55281 Indonesia \\ ${ }^{3}$ Faculty of Medicine, Sebelas Maret University, Jalan Ir. Sutami 36 A, Surakarta, 57126 Indonesia \\ ${ }^{4}$ Department of Physiology, Faculty of Veterinary Medicine, \\ Gadjah Mada University, Jalan fauna no.2, Yogyakarta, 55281 Indonesia \\ ${ }^{5}$ Department of Pathology, Faculty of Veterinary Medicine, \\ Gadjah Mada University, Jalan fauna no.2, Yogyakarta, 55281 Indonesia \\ ${ }^{6}$ Department of Internal Medicine, Faculty of Veterinary Medicine, \\ Gadjah Mada University, Jalan fauna no.2, Yogyakarta, 55281 Indonesia
}

Article history

Received: 26-10-2014

Revised: 20-05-2015

Accepted: 24-08-2015

Corresponding Author: Asmarani Kusumawati Department of Reproduction, Faculty of Veterinary Medicine, Gadjah Mada University, Jalan Sekip Unit II, Yogyakarta, 55281 Indonesia

Centre of Biotechnology Study, Gadjah Mada University, Jalan teknika utara, Yogyakarta, 55281 Indonesia

Email: kartapati_2008@yahoo.com

\begin{abstract}
Jembrana disease constitutes the main concern in cattle industry especially in Indonesia and Australia as it has caused important economic losses due to mortality of cattle. The pathology of the disease is unusual for a lentivirus infection as it is associated with a severe, often lethal disease syndrome and a short incubation period in cattle. For lack of efficient medical treatment of JDV-infected cattle, vaccination may therefore constitute an effective measure for the prevention or eradication of Jembrana disease. Up to date, only one type of vaccine has been reported and tested. It is based on inactivated, tissue-derived virus antigens (Tabanan/87 isolate, $\left.\mathrm{JDV}_{\mathrm{TAB} / 87}\right)$. This review summarize show current Jembrana disease vaccine was developed as well as evaluated and how these information might be useful in future vaccine design.
\end{abstract}

Keywords: Jembrana Disease, Vaccine, Prevention and Control, Bovine Disease, Immunization

\section{Introduction}

Jembrana disease was identified first in the Jembrana district of Bali island in Indonesia as an acute infectious disease (Kusumawati et al., 2014a). During the first observed outbreaks of Jembrana disease, the clinical disease was not reported in other types of cattle and this led to belief that the disease is unique to Bali cattle. Moreover, the mortality of more than 50000 cattles in a year was observed during the first outbreak (Budiarso and Hardjosworo, 1976). The disease is now endemic through-out parts of Indonesia (Hartaningsih et al., 1993) and also in Australia (Chadwick et al., 1998). Jembrana disease poses the major problem in Bali cattle industry especially in Indonesia and Australia due to the high mortality of the infected cattle, resulting in economic loss (Chadwick et al., 1998; Soesanto et al., 1990). The etiological agent, consequently named as
Jembrana Disease Virus (JDV). It belongs to the family of Retroviridae, of the subfamily of lentiviruses (Kusumawati et al., 2014a). The pathological process of JDV infection is quite different from other lentivirus infection as it is related with a short incubation period duration and a severe disease syndrome (Kusumawati et al., 2014b). Fatal issues, due to multiorgan involvement, occur only one to two weeks post-infection. These disease characteristics are in contrast to the chronic and progressive diseases over a long incubation periods typically associated with most lentiviral infections (Wilcox et al., 1995; Wilcox, 1997).

JDV-infected cattle exhibit a delayed and temporarily suppressed humoral response. This provides an explanation for the common occurrence of secondary infections which may lead to fatal issues in affected cattle (Dharma et al., 1991; Teuscher et al., 1982). The finding showed that no recurrence of disease is observed in 
recovered animals and importantly they resist to further infections for at least 22 months (Dharma et al., 1991; Soeharsono et al., 1990). This suggests that JDV infections induce a protective immunity and probably vaccination using denatured or attenuated viral particles, can be performed to limit the disease spread. For lack of efficient medical treatment of JDV-infected cattle, vaccination may therefore constitute an effective measure for the prevention or eradication of Jembrana disease. Up to date, only one type of vaccine has been reported and tested (Ditcham et al., 2009; Hartaningsih et al., 2001). It is based on inactivated, tissue-derived virus antigens (Tabanan/87 isolate, $\mathrm{JDV}_{\mathrm{TAB} / 87}$ ) (Ditcham et al., 2009; Hartaningsih et al., 2001). Presently, the vaccine is commercially available (JDVacc) and is routinely used for controlling the spread of Jembrana disease (Ditcham et al., 2009). This review deals with JDV vaccine which has been developed, summarizing its development, delivery, efficacy and what can be improved in future vaccine design.

\section{Production of JDV Vaccine}

\section{Sources of Virus, Methods of Preparation and Adjuvants}

During the acute phase, high titers of infectious virus are found in plasma and in certain organs such as spleen. They constitute therefore sources for virus production. Plasma-derived antigens were prepared from heparinized blood by low speed centrifugation then concentrated by high speed centrifugation. Spleen-derived antigens were prepared by homogenizing spleen of infected cattle, to provide a $10 \%$ spleen concentration and centrifuged at very low speed. Viruses were inactivated either by formaldehyde or Triton X-100. Two adjuvants were tested: Incomplete Freund's Adjuvant (IFA) or a Mineral Oil Adjuvant (MOA) and the vaccine preparation was emulsified to form a homogenous suspension (Hartaningsih et al., 2001).

\section{Modes of Vaccine Delivery and Challenge}

Vaccination was done by intramuscular inoculation (in neck region) with two or three doses at monthly intervals. The absence of febrile response is taken as an indicator of complete inactivation of virus. Challenge was carried out with virulent $\mathrm{JDV}_{\mathrm{TAB} / 87}$ isolate (Chadwick et al., 1995; Soeharsono et al., 1990) one month following the last vaccine dose. Vaccination response was examined for clinical disease and rectal temperature. Normal criteria for the development of Jembrana disease were a concurrent febrile reaction and leucopenia of two or more days duration. Examination of gross and histopathological lesions of Jembrana disease was also performed at the conclusion of the observation period. Humoral response was established by serological assays, using Western blotting (Hartaningsih et al., 2001).

\section{Effects of Different Factors on Vaccine Efficiency}

Their effects were examined and statistical results are considered as the overall response. Several factors may influence vaccine efficiency as described below (Hartaningsih et al., 2001).

\section{Inactivating Agent}

The effects of formaldehyde and Triton X-100 were examined on plasma-derived virus preparation. Viruses were completely inactivated by both inactivating agents as none of the vaccinated cattle developed a febrile response within 14 days after challenge. Animals, vaccinated with Triton-X100-inactivated viral particles, exhibited either partial or near complete immunity, with milder JDV-specific clinical symptoms following a challenge. Vaccination with formaldehyde-inactivated viruses also induced the production of JDV-specific antibodies though at markedly lower level but the vaccinated animals still developed clinical and haematological changes typical to Jembrana disease. It appeared so that Triton X-100-inactivated viral particles gave more satisfying result although the protective effect of the vaccine was not complete (Hartaningsih et al., 2001).

\section{Adjuvant Efficacy}

Comparison of the efficacy of IFA and a MOA was done using plasma-derived vaccine inactivated with Triton X-100. With both types of vaccine, three doses were required to reduce the duration of febrile state and the disease severity following a challenge. In necropsied cattle, the histological changes were considerably milder. The titers of antibody were similar in both cases and they progressively increased after each dose of vaccine. Antibodies to p26 (capsid protein) were the firstly detected whereas antibodies specific to other viral proteins were only detected after the third vaccine dose. Overall, similar effects were attained with either IFA or a MOA (Hartaningsih et al., 2001).

\section{Influence of Tissue Origin}

The developed JDV vaccines were either plasma- or spleen-derived. Comparison of their efficacy was done by performing vaccination with antigens inactivated with Triton X-100 and emulsified in MOA at monthly intervals. Statistically, examination of the typical clinical signs showed that the spleen-derived vaccines were more efficient than the plasma-derived ones as judged by a greater capacity in reducing the disease severity after challenge. Nevertheless, the level of JDV-specific antibodies was similar in cattle vaccinated with virus preparation from both origins (Hartaningsih et al., 2001). 


\section{Conclusion from Comparative Evaluation}

From results obtained by comparing the effects of different parameters, it can be concluded that the optimal vaccination procedures against Jembrana disease are as follows: Inactivation of the virus in tissues with Triton X-100, use of a MOA and three times vaccination at monthly intervals.

\section{Evaluation of JDV Vaccine}

\section{Pathology of Jembrana Disease}

Understanding the pathological process in JDV infection is important as a basic knowledge for evaluating the effect of vaccine in the progression of the disease. Here we briefly describe the relevant pathological process in the progression of Jembrana disease. Clinically, the inoculated Bali cattle (with blood from an infected JDV cattle) exhibited several clinical signs after a short incubation period of 5 to 12 days, including lethargic state, anorexic state, hyperthermic state $\geq 39.3^{\circ} \mathrm{C}$ persisting for 7 days (rectal temperature), swollen of superficial lymph nodes, pallor in the mucus membrane, a mild ocular and nasal discharge and diarrhoea with fecal blood (Soesanto et al., 1990). Laboratorically, the notified major changes in haematological condition included a normocytic normochronic anaemia, leucopenia (particularly lymphopenia, eosinopenia and a slight neutropenia), a mild thrombocytopenia, elevated blood urea concentrations and reduced total plasma protein (Soesanto et al., 1990). Viruses are also detected in a high titer (up to $10^{8} \mathrm{ID}_{50} / \mathrm{mL}$, equaling to $10^{10}$ to $10^{11}$ viral genome copies $/ \mathrm{ml}$ ) in the plasma fraction of the blood during the febrile state (Soeharsono et al., 1990; Soesanto et al., 1990; Stewart et al., 2005). The majority infected animals cultivate possible amount of antibodies to be detected only 6 weeks or more after recovery from the acute phase of the natural disease (Hartaningsih et al., 1994). The temporary immunosuppression occurring during the acute phase was demonstrated by a decrease of IgG-containing cells in the lymphoid organs (Dharma et al., 1994). However the ratio of IgGcontaining cells raised during convalescence (Dharma et al., 1994). Moreover, a study used Agar Gel Immunodiffusion (AGID) and Enzyme-Linked Immunosorbent Assay (ELISA) showed a slowed antibody response in JDV-infected animals (Desport et al., 2009). Thus antibodies are not thought to be the major factor in the clearance of JDV in the acute phase as humoral immune response is produced several week after natural infection (delayed humoral response phenomenon). The comprehensive review of pathological process in Jembrana disease has been reported elsewhere by Kusumawati et al (2014b).

\section{JDV Vaccine Efficacy}

The spleen-derived JDV vaccine, JDVacc, is a detergent inactivated virus in homogenized spleen, inactivated by Triton X-100 and emulsified by a MOA. Two doses of JDVacc is the currently recommended vaccination regime. The protection provided is not complete, but the reduction of the duration and the disease severity and the infectious period may be sufficient to ameliorate the disease and hence to limit the transmission of virus to susceptible cattle (Ditcham et al., 2009; Hartaningsih et al., 2001). It has been shown that disease transmission possibly occurs when the virus titer is above a threshold below which the risk of disease transmission is highly reduced. In Jembrana disease, the threshold is thought to be $10^{6}$ genome copies $/ \mathrm{mL}$ in plasma, equivalent to $10^{4}$ ID $50 / \mathrm{mL}$ in plasma and a titer of $10^{10}-10^{11}$ genome copies $/ \mathrm{ml}$ is currently observed during the febrile state (Soeharsono et al., 1990; Soesanto et al., 1990; Stewart et al., 2005). Due to the high titers of infectious viral particles, virus transmission is most likely to occur during the acute phase. A vaccine that allows to reduce the duration and the magnitude of viraemia would also reduce the infectious period and the risk of disease transmission. It is therefore essential to evaluate the capability of JDVacc to efficiently reduce the virus titer and consequently the rate of the disease transmission (Ditcham et al., 2009). For this purpose, Bali cattle were vaccinated with two doses of JDVacc, two and one month before challenge (Ditcham et al., 2009). Analyses included determination of the genome copies by real-time RT-PCR as described earlier (Stewart et al., 2005; Kusumawati et al., 2015) and humoral response by Western immunoblot and ELISA using recombinant JDV proteins as previously described (Desport et al., 2005). The vaccine efficacy was determined for different parameters as described below (Ditcham et al., 2009):

\section{Humoral Response}

JDV-infected cattle frequently succumb to secondary infections (Dharma et al., 1991), resulting from transient immunosuppression characteristic to Jembrana disease (Wareing et al., 1999). In spite of this, vaccinated cattle still develop virus specific antibodies following infection. The examination of the humoral response showed that the $\operatorname{IgG}$ response varied following the antigen species. In vaccinated cattle, the seroconversion occurred at 10-25 days post challenge for p16 (matrix protein). Antibody specific to p26 (capside protein) was induced after the first dose of vaccine, increased after the second dose and the level is maintained after challenge. As for anti-TM (transmembrane protein) antibody, it was detected at 
10-25 days post-infection. In non vaccinated animals, there was a delayed seroconversion to JDV p26 and TM at 56 days post infection instead of 10-25 days and none developed anti-p16 IgG (Ditcham et al., 2009).

\section{Clinical Response}

Reduction of the duration and magnitude of febrile response and of the severity of leucopenia are correlates of protective effect of vaccine. This is actually attained with JDVacc. In vaccinated cattle, the duration of the febrile response upon challenge was reduced as compared to control animals and the period of moderate fever was also shorter (Ditcham et al., 2009; Hartaningsih et al., 2001). However the occurrence of febrile response induced at lower levels of virus in vaccinates highlights an opposite effect and shows a balance between effective immune activities and potentiation of viral replication (Ditcham et al., 2009). These confounding effects of vaccination have also been observed in other lentiviral infections (Poli and Fauci, 1993; Richardson et al., 2002).

\section{Genome Copy Number}

The threshold of $10^{6} \mathrm{JDV}$ genome copies $/ \mathrm{ml}$ of plasma is indicative of a high level of viral replication hence of the probability of disease transmission to other animals. Therefore the period during which this threshold is attained, can be considered as the infectious period. All vaccinated animals had a viral load above the threshold level but its magnitude is much lower. Its duration was also reduced. It is thought that the reduction of the duration and of the severity of Jembrana disease and also of the infectious period may be sufficient to reduce the mortality rates and the transmission of virus to susceptible cattle (Ditcham et al., 2009; Hartaningsih et al., 2001).

\section{Virus Clearance}

The most significant effect of JDVacc is the faster virus clearance in vaccinates compared to control animals (Ditcham et al., 2009) although the mechanism involved is not yet fully understood. The lower level of viral load may be due, at least partly, to the humoral response which enables virus neutralization. This will result in the reduction of early virus spreading. The combined elevated rectal temperature with lower virus titers and the effective virus clearance may suggest that the effective virus clearance results from a primed cellmediated immunity response. This aspect has nevertheless been experimented.

\section{Conclusion}

Vaccine trials are not always easy to carry out correctly due to possible individual variations. Testing of potential JDV vaccines is facilitated by the acute nature of Jembrana disease, induced after a short incubation periods. Therefore long periods of monitoring are not required to assess the effects of immunization. The vaccine type which has been developed from spleen of JDV-infected cattle, JDVacc, is the sole that has been tested and presently commercially available and currently used to circumscribe the spread of Jembrana disease (Ditcham et al., 2009; Hartaningsih et al., 2001). Neutralizing antibody is likely not the essential mechanism in recovery from acute Jembrana disease as it is detected in animals only after a prolonged period following recovery from clinical disease (Hartaningsih et al., 1994; Soeharsono et al., 1990). Despite the lack of complete efficacy, the immune response attained in vaccinates appears to be sufficient to reduce the disease severity and the virus infectivity, all the more as naturally resistent Bali cattle will also help to limit disease outbreaks (Desport et al., 2009). The JDVacc trials confirmed the fact that some degree of protection can be achieved against lentivirus diseases by whole virus vaccine, such as Feline Immunodeficiency Virus (FIV) (Bischop et al., 1996; Diehl et al., 1996), Equine Infectious Anaemia Virus (EIAV) (Wang et al., 1994) and Simian Immunodeficiency Virus (SIV) (Vaslin et al., 1994). The use of other types of vaccine, such as recombinant antigens and DNA vaccines, should be explored although some types of recombinant antigen cannot be correctly produced. Recently, a JDV-derived disabled, replicative-defective gene transfer vector has been developed (Metharom et al., 2000; 2001; Olsen, 2001). It can express exogenous genes of interest but it can also be used as a delivery system for JDV gene products such as gag and env products which are difficult to produce in conventional expression plasmids. Such a delivery system can be used to produce important immunogenic antigens simultaneously with factors that enhance the induction of efficient immune response. Jembrana disease constitutes an important concern in cattle industry. As drugs specific to JDV are not available, in combination with suitable health measures and routine health controls, vaccination will constitute an efficient measure to prevent disease outbreaks and to reduce the consequent economic losses.

\section{Acknowledgment}

We acknowledge to Prabowo Purwono Putro, DVM, M.Phil for provided the technical help and other general support.

\section{Funding Information}

This work was partly funded by a grant from Directorate General of Higher Education (DIKTI), Ministry of Education and Culture of Indonesia. 


\section{Author's Contribution}

Asmarani Kusumawati: Participated in all aquisition of literatures, reviewed the literatures, coordinated and contributed the writing of the manuscript.

Tenri Ashari Wanahari: Participated in all aquisition of literatures, reviewed the literatures and contributed the writing of the manuscript.

Pudji Astuti: Provided the technical guidance in literature review and contributed of the writing of the manuscript.

Kurniasih: Reviewed the literatures and provided the technical guidance in literature review.

Basofi Ashari Mappakaya: Contributed the writing of the manuscript.

Hastari Wuryastuty: Provided the technical guidance in literature review.

\section{Ethics}

This study was approved by Research Ethics Commitee, Faculty of Veterinary Medicine, Gadjah Mada University, Indonesia.

\section{References}

Bischop, S.A., C.R. Stokes, T.J. Gruffydd-Jones, C.V. Whiting and R. Oskome et al., 1996. Vaccination with fixed Feline Immunodeficiency Virus (FIV) infected cells: Protection, breakthrough and specificity of response. Vaccine, 14: 1243-1250. DOI: $10.1016 / \mathrm{S} 0264-410 \mathrm{X}(96) 00023-0$

Budiarso, I.T. and S. Hardjosworo, 1976. Jembrana disease in Bali cattle. Aust. Vet. J., 52: 97-97. DOI: 10.1111/j.1751-0813.1976.tb13867.x

Chadwick, B.J., R.J. Coelen, G.E. Wilcox, L.M. Sammels and G. Kertayadnya, 1995. Nucleotide sequence analysis of Jembrana disease virus: A bovine lentivirus associated with an acute disease syndrome. J. Gen. Virol., 76: 1637-50. DOI: 10.1099/0022-1317-76-7-1637

Chadwick, B.J., M. Desport, J. Brownlie, G.E. Wilcox and D.M. Dharma, 1998. Detection of Jembrana disease virus in spleen, lymph nodes, bone marrow and other tissues by in situ hybridization of paraffinembedded sections. J. Gen. Virol., 79: 101-106. PMID: 9460930

Desport, M., W.G.F. Ditcham, J.R. Lewis, T.J. McNab and M.E. Stewart et al., 2009. Analysis of Jembrana disease virus replication dynamics in vivo reveals strain variation and atypical responses to infection. Virology, 386: 310-316.

DOI: $10.1016 /$ j.virol.2009.01.014
Desport, M., M.E. Stewart, C.A. Sheridan, W.G. Ditcham and S. Setiyaningsih et al., 2005. Recombinant Jembrana disease virus gag proteins identify several different antigenic domains but do not facilitate serological differentiation of JDV and nonpathogenic bovine lentiviruses. J. Virol. Methods, 124: 135-42.

DOI: 10.1016/j.jviromet.2004.11.015

Dharma, D.M., A. Budiantono, R.S. Campbell and P.W. Ladds, 1991. Studies on experimental Jembrana disease in Bali cattle. III. Pathology. J. Comp. Pathol., 105: 397-414. DOI: $10.1016 / \mathrm{S} 0021-9975(08) 80109-0$

Dharma, D.M., P.W. Ladds, G.E. Wilcox and R.S. Campbell, 1994. Immunopathology of experimental Jembrana disease in Bali cattle. Vet. Immunol. Immunopathol., 44: 31-44. PMID: 7725629

Diehl, L.J., C.K. Mathiason-Dubard, L.L. O’Neil and E.A. Hoover, 1996. Plasma viral RNA load predicts disease progression in accelerated feline immunodeficiency virus infection. J. Virol., 70: 2503-2507. PMID: 8642679

Ditcham, W.G.F., J.R. Lewis, R.J. Dobson, N. Hartaningsih and G.E. Wilcox et al., 2009. Vaccination reduces the viral load and the risk of transmission of Jembrana disease virus in Bali cattle. Virology, 386: 317-324.

DOI: 10.1016/j.virol.2009.02.008

Hartaningsih, N., D.M. Dharma, S. Soeharsono and G.E. Wilcox, 2001. The induction of a protective immunity against Jembrana disease in cattle by vaccination with inactivated tissue-derived virus antigens. Vet. Immunol. Immunopathol., 26: 163-76. DOI: 10.1016/S0165-2427(00)00265-8

Hartaningsih, N., G.E. Wilcox, D.M. Dharma and M. Soetrisno, 1993. Distribution of Jembrana disease in cattle in Indonesia. Vet. Microbiol., 38: 23-29. DOI: 10.1016/0378-1135(93)90072-F

Hartaningsih, N., G.E. Wilcox, G. Kertayadnya and M. Astawa, 1994. Antibody response to Jembrana disease virus in Bali cattle. Vet. Microbiol., 39: 15-23. PMID: 8203120

Kusumawati, A., T.A. Wanahari, R.F. Putri, B.A. Mappakaya and I.D. Tampubolon, 2014a. The structure and function of Jembrana disease virus genome. J. Inform. Mol. Biol. Sci., 2: 26-29. DOI: $10.14737 /$ jimb.2307-5465/2.2.26.29

Kusumawati, A., T.A. Wanahari, R.F. Putri, T. Untari and T. Hartati et al., 2014b. Clinical and pathological perspectives of Jembrana disease virus infection: A review. Biosci. Biotech. Res. Asia., 11: 1221-1225. DOI: $10.13005 / \mathrm{bbra} / 1509$ 
Kusumawati A., T.A. Wanahari, I.D. Tampubolon and B.A. Mappakaya, 2015. The comparison of RTLAMP, RT-PCR and Dot-Blot hybridization for detection of jembrana disease virus. Am. J. Biochem. Biotechnol., 11: 114-118. DOI: 10.3844/ajbbsp.2015.114.118

Metharom, P., S. Takyar, H.H. Xia, K.A. Ellem and J. Macmillan et al., 2000. Novel bovine lentiviral vectors based on Jembrana disease virus. J. Gene Med., 2: 176-185. PMID: 10894263

Metharom, P., S. Takyar, H.Q. Xia, K.A. Ellem and G.E. Wilcox et al., 2001. Development of disabled, replication-defective gene transfer vectors from the Jembrana disease virus, a new infectious agent of cattle. Vet. Microbiol., 3: 9-22. PMID: 11278119

Olsen, J.C., 2001. EIAV, CAEV and other lentivirus vector systems. Somat. Cell Mol. Genet., 26: 131-145. PMID: 12465465

Poli, G. and A.S. Fauci, 1993. Cytokine modulation of HIV expression. Semin. Immunol., 5: 165-173. PMID: 7688596

Richardson, J., S. Broche, S. Baud, T. Leste-Lasserre and F. Femenia et al., 2002. Lymphoid activation: a confounding factor in AIDS vaccine development? J. Gen. Virol., 83: 2515-2521. PMID: 12237435

Soeharsono, S., N. Hartaningsih, M. Soetrisno, G. Kertayadnya and G.E. Wilcox, 1990. Studies of experimental Jembrana disease in Bali cattle. I. Transmission and persistence of the infectious agent in ruminants and pigs and resistance of recovered cattle to re-infection. J. Comp. Pathol., 103: 49-59. PMID: 2394846

Soesanto, M., S. Soeharsono, A. Budiantono, K. Sulistyana and M. Tenaya et al., 1990. Studies on experimental Jembrana disease in Bali cattle. II. Clinical signs and haematological changes. J. Comp. Pathol., 103: 61-71. PMID: 2394847
Stewart, M., M. Desport, N. Hartaningsih and G. Wilcox, 2005. TaqMan real-time reverse transcription-PCR and JDVp26 antigen capture enzyme-linked immunosorbent assay to quantify Jembrana disease virus load during the acute phase of in vivo infection. J. Clin. Microbiol., 43: 5574-5580. PMID: 16272489

Teuscher, E., S. Ramachandran and H.P. Harding, 1982. Is "Bali disease" in cattle a late complication of "'Jembrana disease"? ZentralblVeterinarmed A., 29: 547-556. PMID: 6815930

Vaslin, B., R. Le Grand, G. Vogt, O. Benveniste and G. Gras et al., 1994. Induction of humoral and cellular immunity to simian immunodeficiency virus that are the requirements for protection? Vaccine, 12: 1132-1140. PMID: 7998424

Wang, S.Z.S., K.E. Rushlow, C.J. Issel, R.F. Cook and S.J. Cook et al., 1994. Enhancement of EIAV replication and disease by immunization with baculovirus-expressed recombinant envelope surface glycoprotein. Virology, 199: 247-251. PMID: 8116252

Wareing, S., N. Hartaningsih, G.E. Wilcox and W.J. Penhale, 1999. Evidence for immunosuppression associated with Jembrana disease virus infection of cattle. Vet. Microbiol., 16: 179-185. PMID: 10501175

Wilcox, G.E., 1997. Jembrana disease. Aust. Vet. J., 75: 492-493. DOI: 10.1111/j.1751-0813.1997.tb14379.x

Wilcox, G.E., B.J. Chadwick and G. Kertayadnya, 1995. Recent advances in the understanding of Jembrana disease. Vet. Microbiol., 46: 249-255. DOI: 10.1016/0378-1135(95)00089-S 